Article

\title{
Enhancing the Reduction of High-Aluminum Iron Ore by Synergistic Reducing with High-Manganese Iron Ore
}

\author{
Xianlin Zhou ${ }^{1,2,3}$, Yanhong Luo ${ }^{1,3, *}$, Tiejun Chen ${ }^{1,3}$ and Deqing Zhu ${ }^{2, *}$ \\ 1 Hubei Key Laboratory for Efficient Utilization and Agglomeration of Metallurgic Mineral Resources, \\ Wuhan University of Science and Technology, Wuhan 430081, China; xlzhou@wust.edu.cn (X.Z.); \\ chentiejun@wust.edu.cn (T.C.) \\ 2 School of Mineral Processing and Bioengineering, Central South University, Changsha 410083, China \\ 3 School of Resource and Environmental Engineering, Wuhan University of Science and Technology, \\ Wuhan 430081, China \\ * Correspondence: yhluo@wust.edu.cn (Y.L.); dqzhu@csu.edu.cn (D.Z.); \\ Tel.: +86-027-6886-2204 (Y.L.); +86-731-8883-6942 (D.Z.)
}

Received: 29 November 2018; Accepted: 19 December 2018; Published: 22 December 2018

\begin{abstract}
How to utilize low grade complex iron resources is an issue that has attracted much attention due to the continuous and huge consumption of iron ores in China. High-aluminum iron ore is a refractory resource and is difficult to upgrade by separating iron and alumina. An innovative technology involving synergistic reducing and synergistic smelting a high-aluminum iron ore containing $41.92 \% \mathrm{Fe}_{\text {total }}, 13.74 \% \mathrm{Al}_{2} \mathrm{O}_{3}$, and $13.96 \% \mathrm{SiO}_{2}$ with a high-manganese iron ore assaying $9.24 \% \mathrm{Mn}_{\text {total }}$ is proposed. The synergistic reduction process is presented and its enhancing mechanism is discussed. The results show that the generation of hercynite $\left(\mathrm{FeAl}_{2} \mathrm{O}_{4}\right)$ and fayalite $\left(\mathrm{Fe}_{2} \mathrm{SiO}_{4}\right)$ leads to a low metallization degree of $66.49 \%$ of the high-aluminum iron ore. Over $90 \%$ of the metallization degree is obtained by synergistic reducing with $60 \%$ of the high-manganese iron ore. The mechanism of synergistic reduction can be described as follows: $\mathrm{MnO}$ from the high-manganese ore chemically combines with $\mathrm{Fe}_{2} \mathrm{SiO}_{4}$ and $\mathrm{FeAl}_{2} \mathrm{O}_{4}$ to generate $\mathrm{Mn}_{2} \mathrm{SiO}_{4}, \mathrm{MnAl}_{2} \mathrm{O}_{4}$ and $\mathrm{FeO}$, resulting in higher activity of $\mathrm{FeO}$, which can be reduced to $\mathrm{Fe}$ in a $\mathrm{CO}$ atmosphere. The main products of the synergistic reduction process consist of $\mathrm{Fe}, \mathrm{Mn}_{2} \mathrm{SiO}_{4}$, and $\mathrm{MnAl}_{2} \mathrm{O}_{4}$.
\end{abstract}

Keywords: high-aluminum iron ore; synergistic reduction; high-manganese iron ore; hercynite; fayalite

\section{Introduction}

In 2017, 87.47\% of 1229 million tons of iron ore consumed by the Chinese iron steel industry were imported [1]. With the increasing consumption of good-quality iron ores, the poor, fine, and complex domestic iron ore resources cannot meet the huge demand of the iron and steel industry in China. Thus, it is important to utilize low grade iron resources efficiently [2], such as high-aluminum iron resources including high-aluminum limonite and red mud, which is a residue generated after the clarification of bauxite [3].

High-aluminum iron ore is a typical refractory iron resource, which is difficult to upgrade by physical processes due to the superfine size and close dissemination of iron minerals with gangue minerals [4]. Some were directly used as a sintering raw material at a low ratio, which affected the sintering process adversely [5]. Therefore, many separating approaches have been published for high-aluminum iron resources, which can be classified as: (1) physical processes like gravity concentration and magnetic separation [6,7] and flotation [8], (2) pyrometallurgical processes containing solid-state reduction [4,9-12], and smelting [12-15]. So far, iron and aluminum cannot be 
separated completely by physical processes and flotation processes, and more than $10 \%$ of sodium additive is required by the solid-state sodium roasting process, leading to a high risk of the degradation of refractory materials in furnaces [16] and higher costs. In the smelting process, iron ore was mixed with coal and binder to make briquettes and then smelted in a melter to separate the iron and slag over $1550{ }^{\circ} \mathrm{C}$ [17], where iron and aluminum can be isolated entirely. Nevertheless, $\mathrm{Al}_{2} \mathrm{O}_{3}$ affects the viscosity and desulfurizing capacity of blast furnace slag a lot [18], causing a limit usage of the high-aluminum resources in a blast furnace. In order to elevate the ratio of high-aluminum iron resources in the smelting process, a novel technology of synergistic reducing and synergistic smelting the high-aluminum iron ore with a high-manganese iron ore is proposed, and the synergistic reduction process is presented in this paper to discuss its enhancing mechanism.

\section{Materials and Methods}

\subsection{Raw Materials}

The chemical analysis of a high-aluminum iron ore (HA ore) and a high-manganese iron ore (HM ore) are given in Table 1. The two iron ores are both low iron grade, and the HA ore contains high contents of alumina and silica, while high manganese content was observed in the HM ore, assaying 9.24\%. XRD results in Figure 1 illustrate that iron minerals in the two ores consist of hematite and goethite, the aluminum and silica minerals are kaolinite and gibbsite, and the manganese mineral in the HM ore is pyrolusite. Former results showed that hematite in the HA ore is closely included with kaolinite [19]. Figure 2 indicates that iron mineral is surrounded by kaolinite, and that pyrolusite and kaolinite are closely associated with each other. Complex mineral compositions and microstructures in the two iron ores led to significant difficulties in the separation of iron and gangue.

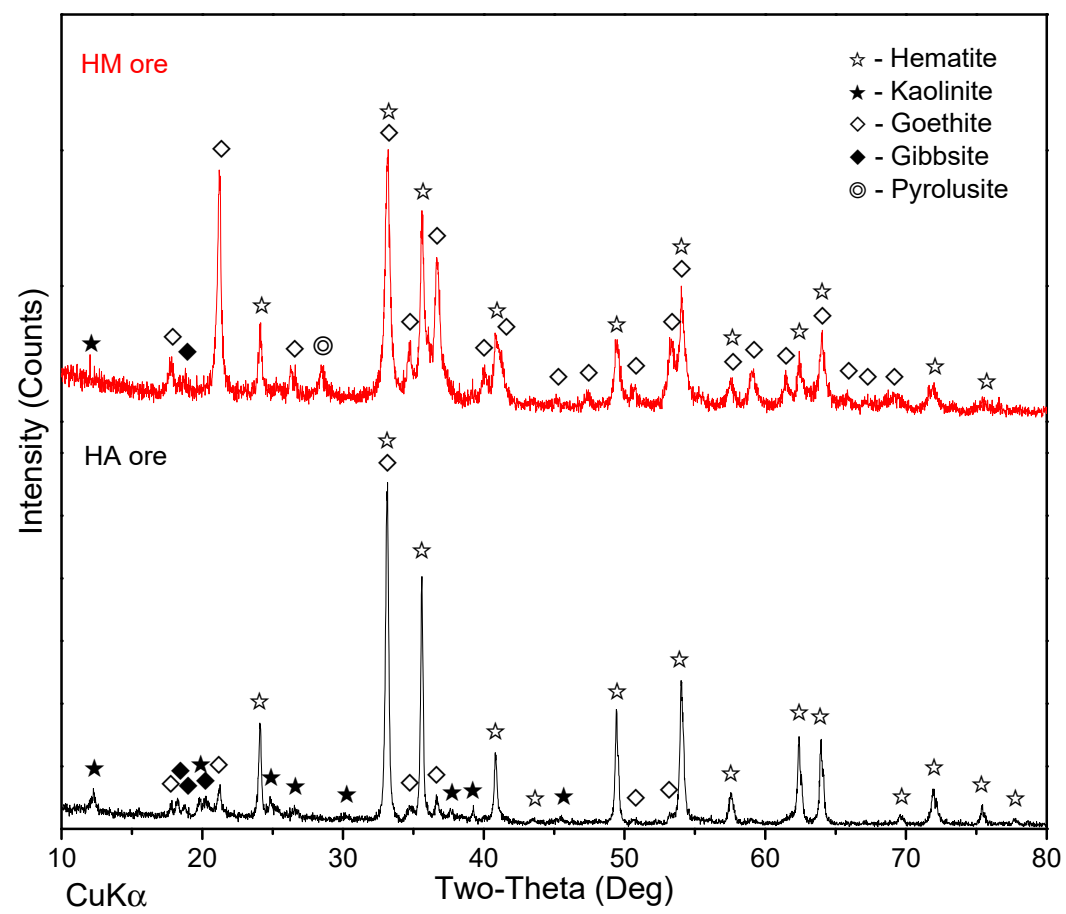

Figure 1. X-ray diffraction (XRD) pattern of high-aluminum iron ore (HA ore) and high-maganese iron ore (HM ore).

A soft coal was used as the reducer during the tests, which contained $52.12 \%$ fixed carbon on an air dry basis (FCad), 30.41\% volatile matter on a dry ash free (Vdaf) basis, $4.49 \%$ ash on an air dry basis (Aad), $0.58 \% \mathrm{~S}$ and a melting temperature of $1376{ }^{\circ} \mathrm{C}$. The size distribution of the soft coal is $100 \%$, passing at $5 \mathrm{~mm}$. 
Table 1. Chemical compositions of raw materials (wt. \%).

\begin{tabular}{cccccccccccc}
\hline Ores & $\mathrm{Fe}_{\text {total }}$ & $\mathrm{Mn}_{\text {total }}$ & $\mathrm{Al}_{2} \mathbf{O}_{3}$ & $\mathrm{SiO}_{2}$ & $\mathbf{C a O}$ & $\mathbf{M g O}$ & $\mathbf{P b}$ & $\mathbf{Z n}$ & $\mathbf{P}$ & $\mathrm{S}$ & LOI \\
\hline $\begin{array}{c}\text { High-aluminum } \\
\text { iron ore (HA ore) }\end{array}$ & 41.92 & 1.24 & 13.74 & 13.96 & 0.13 & 0.88 & 0.64 & 0.21 & 0.130 & 0.014 & 7.20 \\
$\begin{array}{c}\text { High-manganese } \\
\text { iron ore (HM ore) }\end{array}$ & 42.32 & 9.24 & 6.60 & 4.22 & 0.20 & 0.20 & 1.86 & 0.98 & 0.065 & 0.018 & 11.05 \\
\hline
\end{tabular}

Note: LOI, loss on ignition.

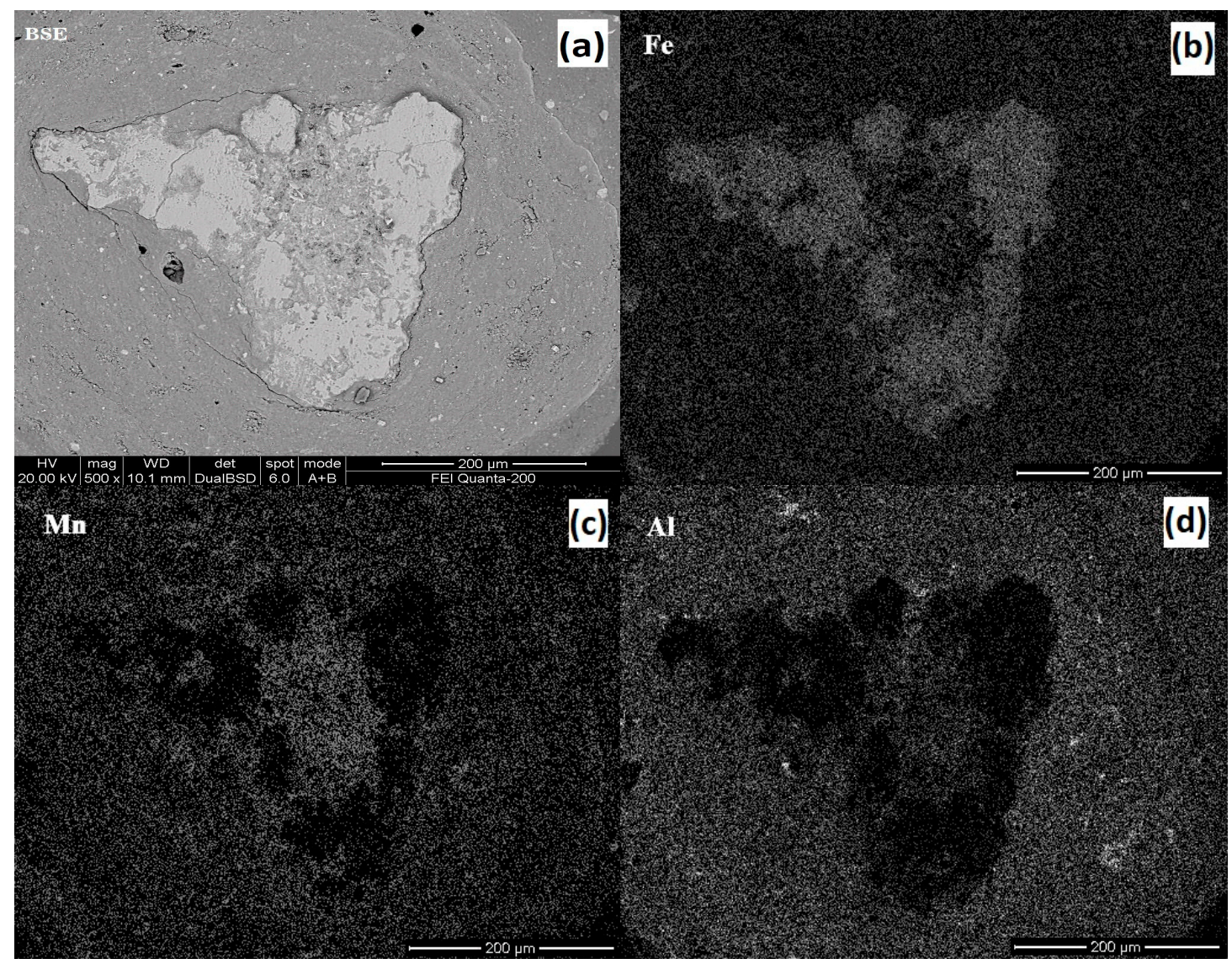

Figure 2. Representative SEM-BSE micrographs of HM ore. (BSE in (a), Back Scattered Electron Imaging; Fe element in (b); Mn element in (c); $\mathrm{Al}$ element in (d)).

\subsection{Experimental Procedures}

The reduction process includes procedures as follows: mixing the two iron ores at a given ratio, pelletizing of the mixture, and reduction roasting of dried pellets. Different experimental conditions of the reduction tests are summarized in Table 2.

Mixtures were prepared by mixing the two iron ores under different ratios, where the fraction of added HM ore is referred to the mixture of two ores. Then, green balls were made by balling the mixtures in a disc pelletizer of $0.8 \mathrm{~m}$ in diameter and a $0.2 \mathrm{~m}$ rim depth, rotating at $38 \mathrm{rpm}$ and being inclined at $47^{\circ}$ to the horizontal. The screened green balls of $8-16 \mathrm{~mm}$ were loaded into the drying oven to dry at $105^{\circ} \mathrm{C}$ for $2 \mathrm{~h}$ until the weight was unchanged.

The dried pellets were put into a stainless steel crucible and covered by some soft coal, where the mass of soft coal was determined by the $\mathrm{C} / \mathrm{Fe}$ mass ratio, which was calculated on the whole available iron content of the pellets. The crucible was loaded into a vertical furnace diagramed in Figure 3 (model: SK-8-13, The Great Wall Furnace, Changsha, China) and roasted for a given reduction time while the reducing temperature was elevated to the target value. After that, the reduced pellets were unloaded and cooled down by covering with pulverized coal. 
Table 2. Different experimental conditions of the reduction tests.

\begin{tabular}{ccccc}
\hline $\begin{array}{c}\text { Series } \\
\text { No. }\end{array}$ & $\begin{array}{c}\text { High-Aluminum Iron Ore: } \\
\text { High-Maganese Iron Ore } \\
\text { (HA:HM) Ratio }\end{array}$ & C/Fe Mass Ratio & Temperature & Reduction Duration \\
\hline & $100: 0$ & 1.5 & $\begin{array}{c}800{ }^{\circ} \mathrm{C}, 850{ }^{\circ} \mathrm{C}, 900^{\circ} \mathrm{C}, \\
950^{\circ} \mathrm{C}, 1000^{\circ} \mathrm{C},\end{array}$ & $60 \mathrm{~min}$ \\
1 & & & $1050{ }^{\circ} \mathrm{C}, 1100^{\circ} \mathrm{C}$ & $15 \mathrm{~min}, 30 \mathrm{~min}, 45 \mathrm{~min}$, \\
2 & $100: 0$ & 1.5 & $1050{ }^{\circ} \mathrm{C}$ & $\begin{array}{c}60 \mathrm{~min}, 75 \mathrm{~min}, 90 \mathrm{~min}, \\
120 \mathrm{~min}\end{array}$ \\
3 & $100: 0$ & $0.5,1.0,1.5,2.0$ & $1050^{\circ} \mathrm{C}$ & $90 \mathrm{~min}$ \\
4 & $100: 0,80: 20,60: 40,40: 60$, & 1.5 & $1050{ }^{\circ} \mathrm{C}$ & $90 \mathrm{~min}$ \\
\hline
\end{tabular}

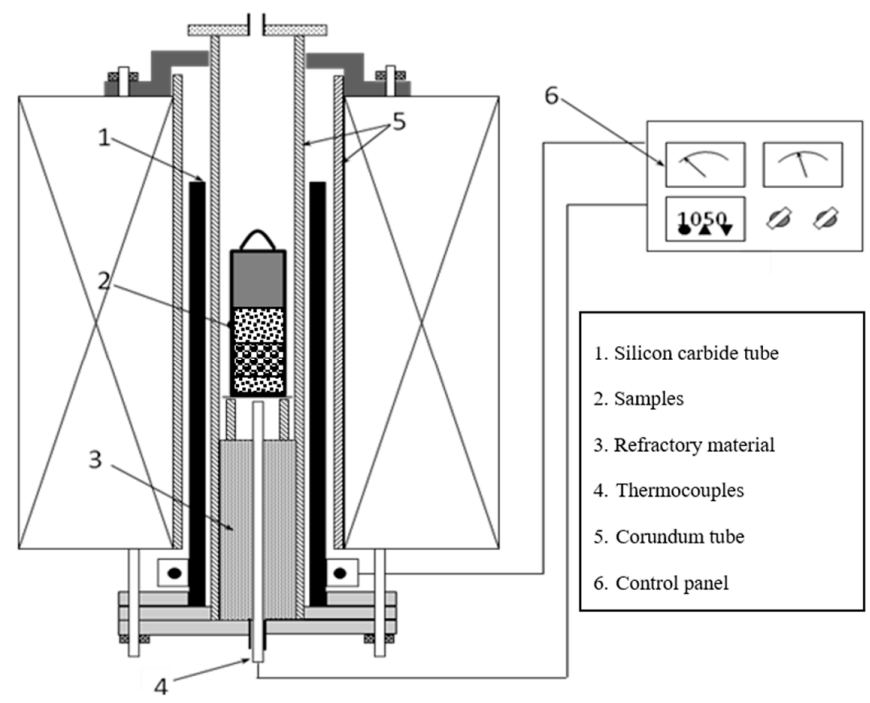

Figure 3. Schematic of vertical furnace for reduction.

X-ray fluorescence spectroscopy (XRF, PANalytical Axios mAX, PANalytical B.V., Almelo, The Netherlands) and chemical analysis were applied for the chemical compositions of raw materials and the reduced pellets. The crystalline phase compositions of the materials were detected by an X-ray diffractometer (XRD, D/Max-2500, Rigaku Co., Tokyo, Japan). Proximate analysis of coal was conducted by the Chinese standards GB/T212-2008. Microstructures of raw materials were observed by a scanning electron microscope (SEM, FEI Quanta-200, FEI Company, GG Eindhoven, The Netherlands) and an optical microscope (DMI4500P, Leica, Wetzlar, Germany), respectively. The compositional analyses were carried out using an energy dispersion system (EDAX-TSL, Ametek Inc., Paoli, CO, USA) within the SEM. Microstructures of reduced pellets were observed by an optical microscope. Metallization degree was applied to evaluate the reduction results, where the metallization degree was determined by the ratio between metallic iron on total iron of the reduced pellets according to ISO 11258:2015.

\section{Results}

\subsection{Effect of Reduction Temperature}

The single HA ore pellets were reduced by optimizing the reduction parameters, to reveal the reducibility of HA ore. The effect of reduction temperature on the metallization degree of HA reduced pellets is shown in Figure 4 under reducing for $60 \mathrm{~min}$ with $\mathrm{C} / \mathrm{Fe}$ mass ratio of 1.5. It was discovered that the metallization degree rose at first, then decreased, and the peak appeared at $1050{ }^{\circ} \mathrm{C}$. Only $53.68 \%$ of the best value of the metallization degree was obtained, declaring a weak reducibility of the HA ore. 


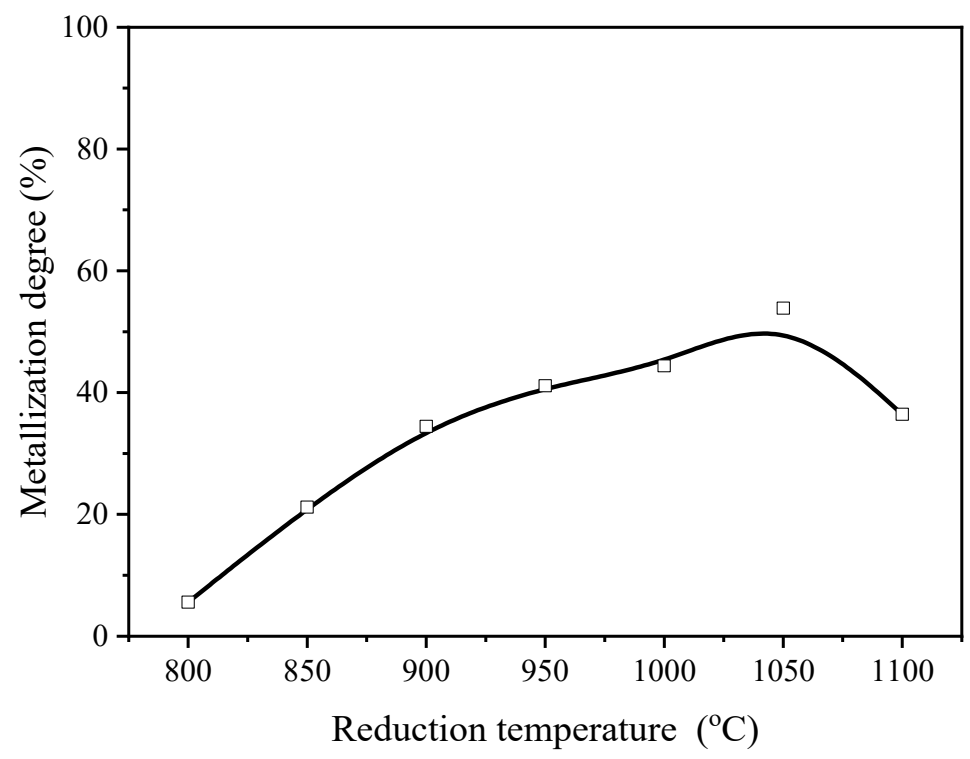

Figure 4. Effect of reduction temperature on metallization degree of reduced pellets of high-aluminum iron ore (HA ore) (reducing for $60 \mathrm{~min}$ with $\mathrm{C} / \mathrm{Fe}$ mass ratio of 1.5).

\subsection{Effect of Reduction Duration}

Figure 5 presents the reduction duration effect result on the metallization of reduced pellets. By prolong the reduction from $15 \mathrm{~min}$ to $30 \mathrm{~min}$, an obvious improvement from $41.86 \%$ to $55.29 \%$ is achieved. Generally, a subtle enhanced trend is found. However, still low metallization degrees are shown in Figure 5. Only $66.49 \%$ of the metallization degree is obtained by reducing the HA pellets for $120 \mathrm{~min}$, which is far lower than that of high grade iron concentrate pellets [20].

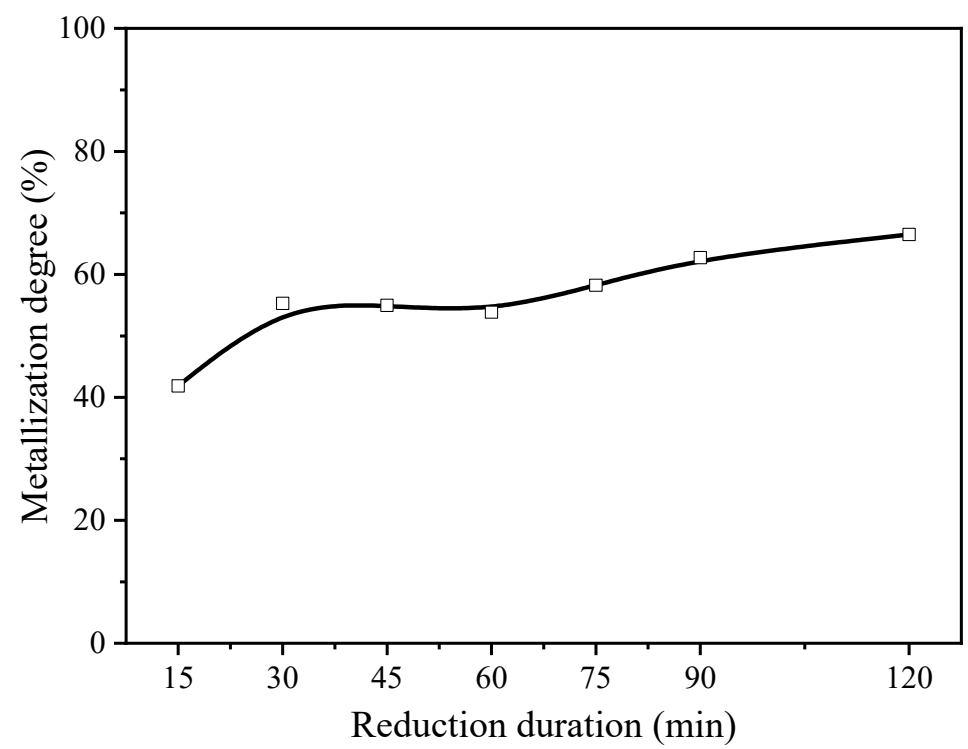

Figure 5. Effect of reduction duration on metallization of reduced pellets of high-aluminum iron ore (HA ore) (reducing at $1050{ }^{\circ} \mathrm{C}$ with $\mathrm{C} / \mathrm{Fe}$ mass ratio of 1.5).

\subsection{Effect of Reductant Ratio}

As shown in Figure 6, the metallization degree of reduced pellets of HA ore increases slightly and then remains steady when the $\mathrm{C} / \mathrm{Fe}$ mass ratio is elevated from 0.5 to 2.0. However, only part of the iron was reduced to metallic iron, where the best value only $62.72 \%$ is obtained. 


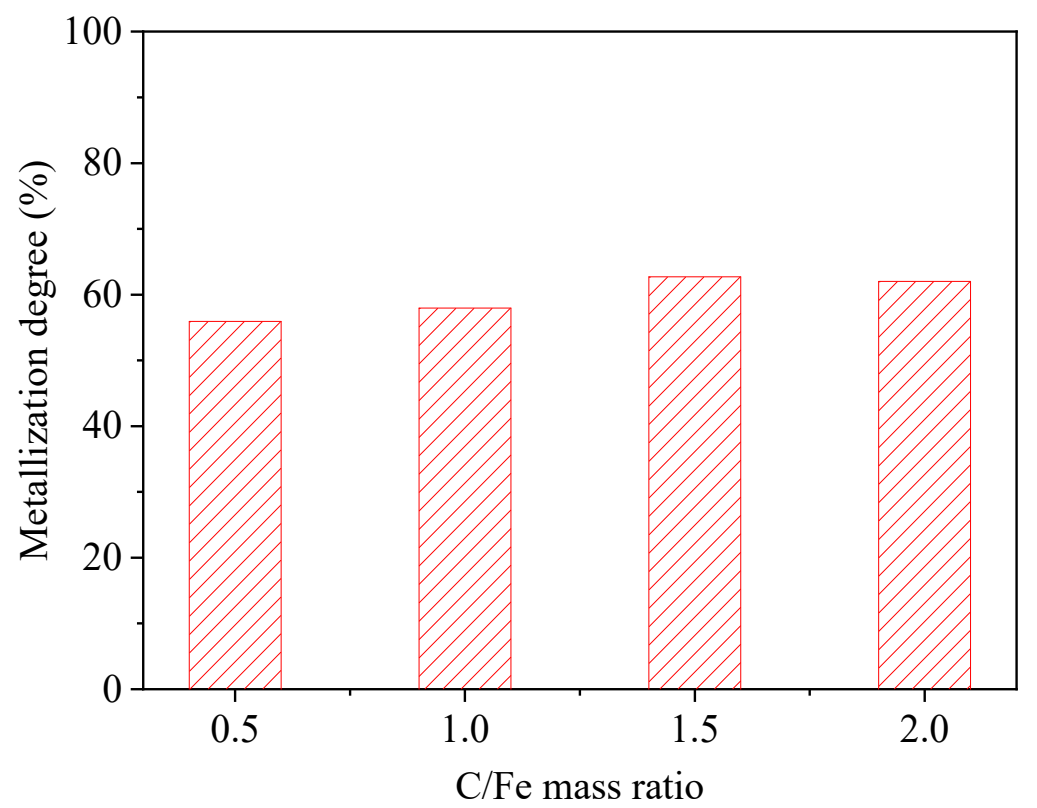

Figure 6. Effect of $\mathrm{C} / \mathrm{Fe}$ mass ratio on metallization of reduced pellets of high-aluminum iron ore (HA ore) (reducing at $1050^{\circ} \mathrm{C}$ for $90 \mathrm{~min}$ ).

\subsection{Effect of HM Ore Ratio}

From the above optimization results of the reduction process, it can be concluded that the HA ore has poor reducibility. Thus, the HM ore was blended with the HA ore to investigate the effect of HM ore on the reduction behavior of HA ore. It can be observed from Figure 7 that the metallization degree increases continuously by raising the $\mathrm{HM}$ ore ratio. Meanwhile, the reduction of pellets is promoted by prolonging the reduction duration. The distributions of metallic iron grains in Figure 8 signify that more obvious iron grains form by blending with more HM ore.

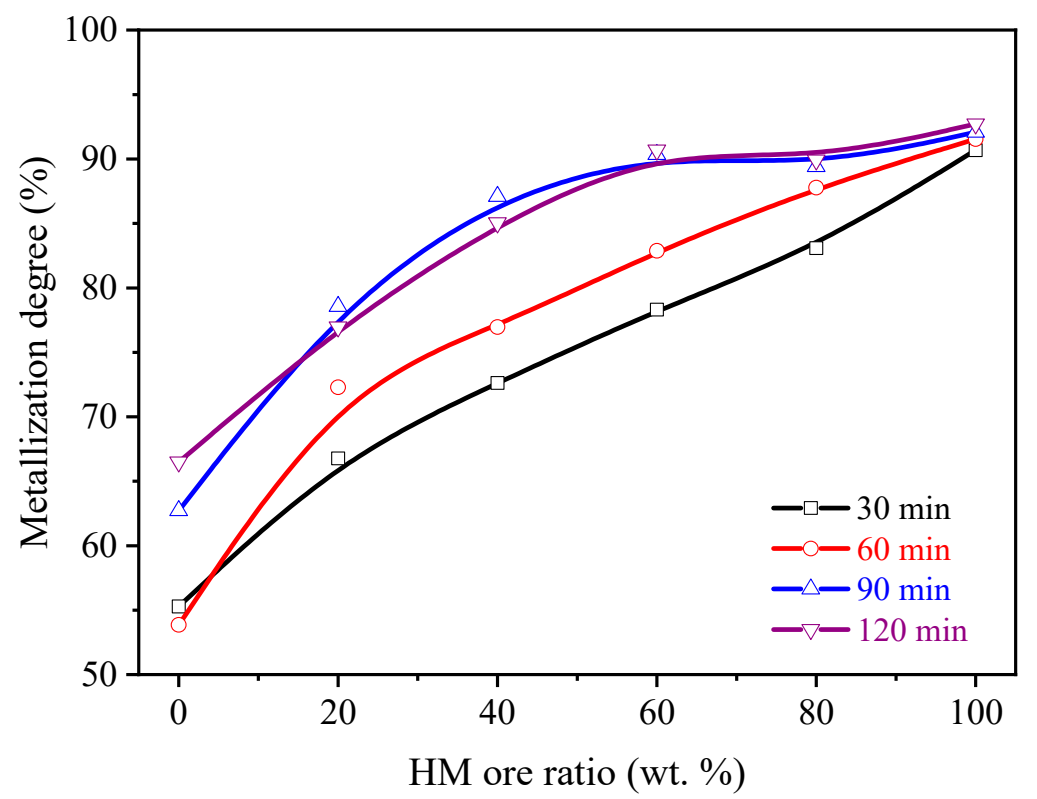

Figure 7. Effect of ratio of high-manganese iron ore (HM ore) in blend on metallization degree of reduced pellets (reducing at $1050{ }^{\circ} \mathrm{C}$ with $\mathrm{C} / \mathrm{Fe}$ mass ratio of 1.5 ). 


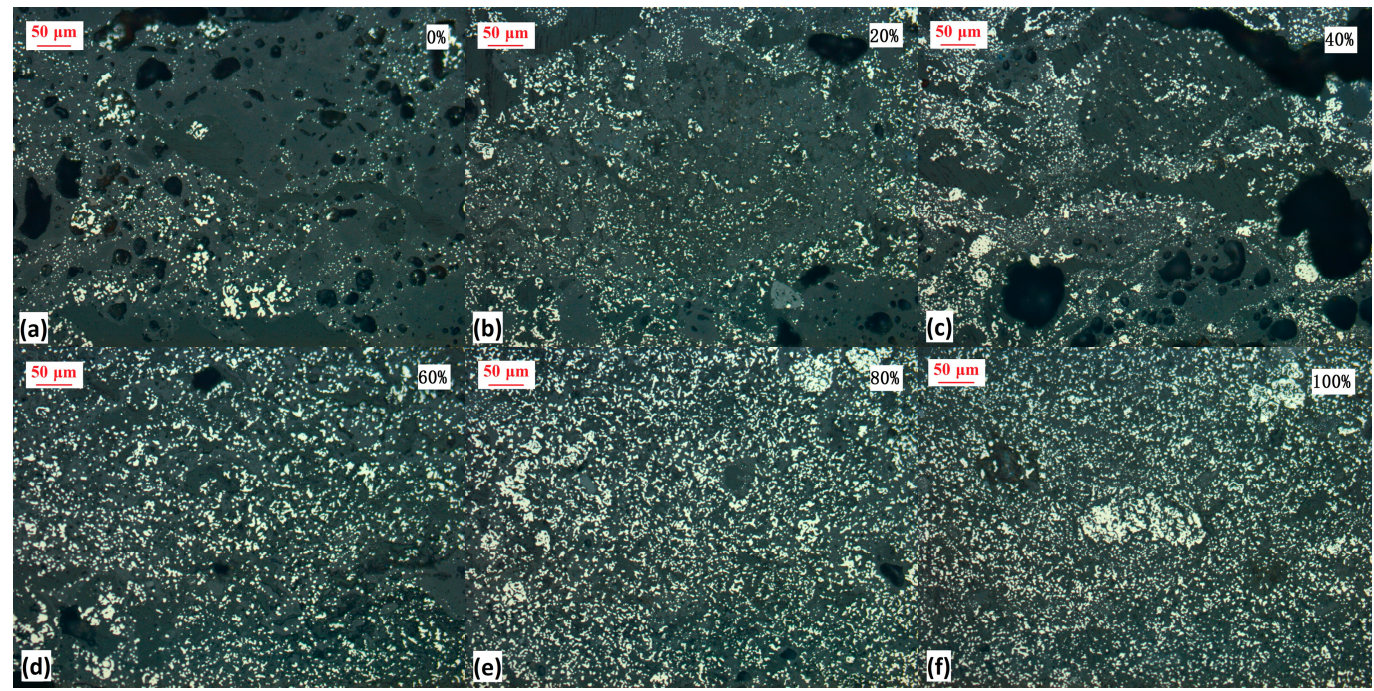

Figure 8. Effect of high-manganese iron ore (HM ore) ratio from $0 \%$ to $100 \%$ (a-f) on distribution of metallic iron grains (white color) in reduced pellets (reducing at $1050{ }^{\circ} \mathrm{C}$ for 90 min with $\mathrm{C} / \mathrm{Fe}$ mass ratio of 1.5).

\section{Discussion}

XRD results of HA reduced pellets under different temperatures are illustrated in Figure 9. Note that fayalite can easily form during the reduction of HA ore. Meanwhile, the diffraction peak intensities of hercynite increase sharply with ascending temperatures, while those of fayalite weaken. According to the thermodynamic criterion, both fayalite and hercynite could not be reduced by $\mathrm{CO}$ when the temperature ranged from $800{ }^{\circ} \mathrm{C}$ to $1100^{\circ} \mathrm{C}$, causing low metallization of HA reduced pellets. Moreover, weaker peak intensity of iron and stronger of fayalite were detected at $1100{ }^{\circ} \mathrm{C}$. Dynamically, the reduction from $\mathrm{FeO}$ to $\mathrm{Fe}$ is the restrictive step of reduction of iron ore [21]. Thus, there is more probability of forming fayalite by the chemical combination of $\mathrm{FeO}$ and $\mathrm{SiO}_{2}$ during the reduction process, leading to a decrease of the metallization degree of the reduced HA pellets at $1100{ }^{\circ} \mathrm{C}$.

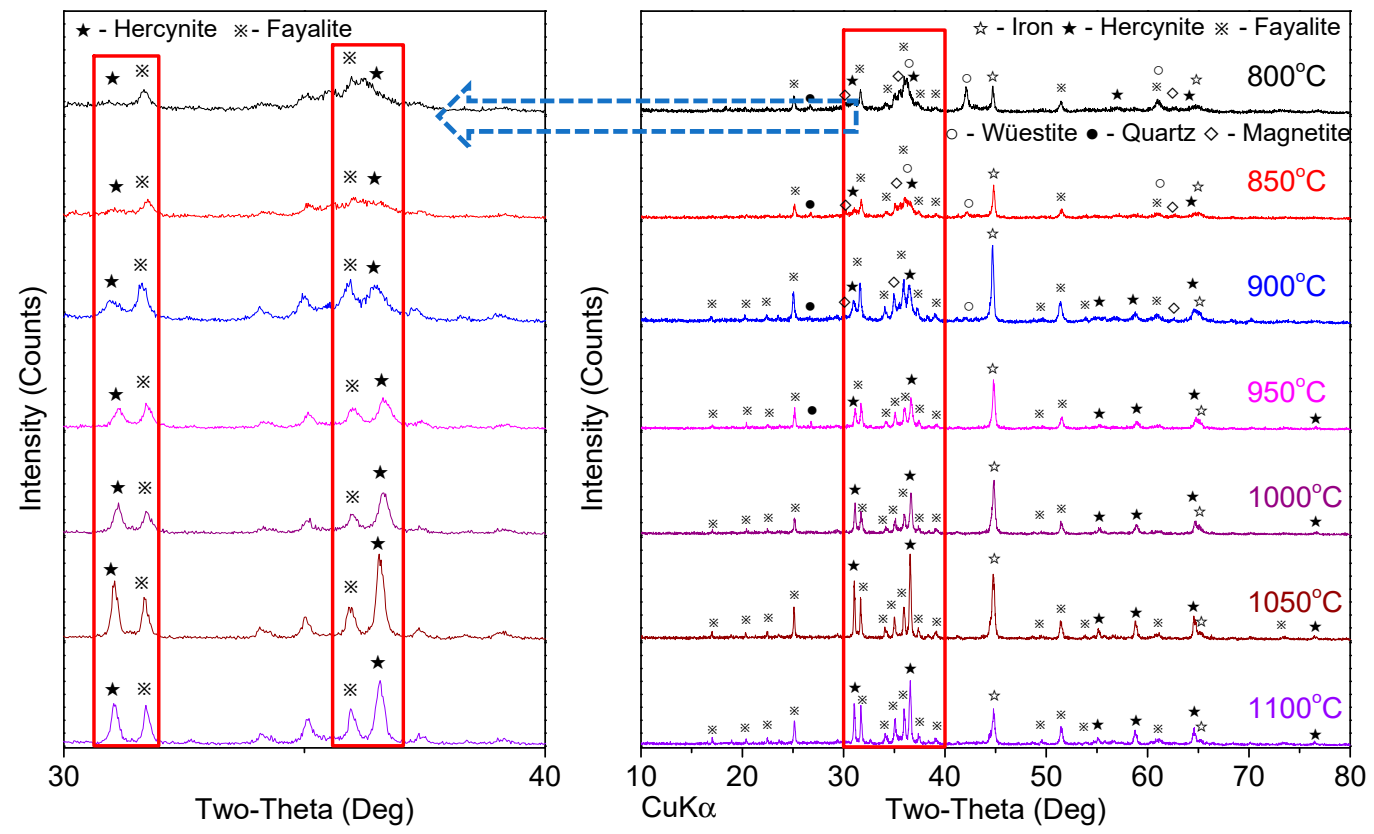

Figure 9. Effect of reduction temperature on mineral compositions of high-aluminum iron ore (HA) reduced pellets (reducing for $60 \mathrm{~min}$ with $\mathrm{C} / \mathrm{Fe}$ mass ratio of 1.5). 
A thermodynamic simulation of a system based on the compositions of the HA ore was processed by FactSage7.1 (Thermfact/CRCT, Montreal, QC, Canada; GTT-Technologies, Herzogenrath, Germany), and the result is depicted in Figure 10 as phase fraction as a function of temperature. The simulation is based on reaching equilibrium at every temperature, and only solid phases and gaseous (not shown) are considered. The $\mathrm{Fe}_{2} \mathrm{O}_{3}$ is already reduced to $\mathrm{Fe}$ at $800{ }^{\circ} \mathrm{C}$ when the simulation starts. However, $\mathrm{Fe}_{2} \mathrm{SiO}_{4}$ and $\mathrm{FeAl}_{2} \mathrm{O}_{4}$ also appear. $\mathrm{Fe}_{2} \mathrm{Al}_{4} \mathrm{Si}_{5} \mathrm{O}_{18}$ appears at $850{ }^{\circ} \mathrm{C}$ and the content increases. The largest variation in concentration is at $975{ }^{\circ} \mathrm{C}$, when $\mathrm{Mn}_{2} \mathrm{Al}_{4} \mathrm{Si}_{5} \mathrm{O}_{18}$ totally disappear to the benefit of $\mathrm{Fe}_{2} \mathrm{Al}_{4} \mathrm{Si}_{5} \mathrm{O}_{18}$ and $\mathrm{Mn}_{3} \mathrm{Al}_{2} \mathrm{Si}_{3} \mathrm{O}_{12}$. According to the simulation result, less than $50 \%$ of $\mathrm{Fe}_{2} \mathrm{O}_{3}$ was reduced to $\mathrm{Fe}$ by $\mathrm{CO}$ between $800{ }^{\circ} \mathrm{C}$ to $1100{ }^{\circ} \mathrm{C}$, while other iron was composed of $\mathrm{Fe}_{2} \mathrm{SiO}_{4}, \mathrm{FeAl}_{2} \mathrm{O}_{4}$ and $\mathrm{Fe}_{2} \mathrm{Al}_{4} \mathrm{Si}_{5} \mathrm{O}_{18}$. This indicates that it is difficult to further achieve a better metallization degree only by an optimization of a combination of time, temperature, and $\mathrm{C} / \mathrm{Fe}$ ratio.

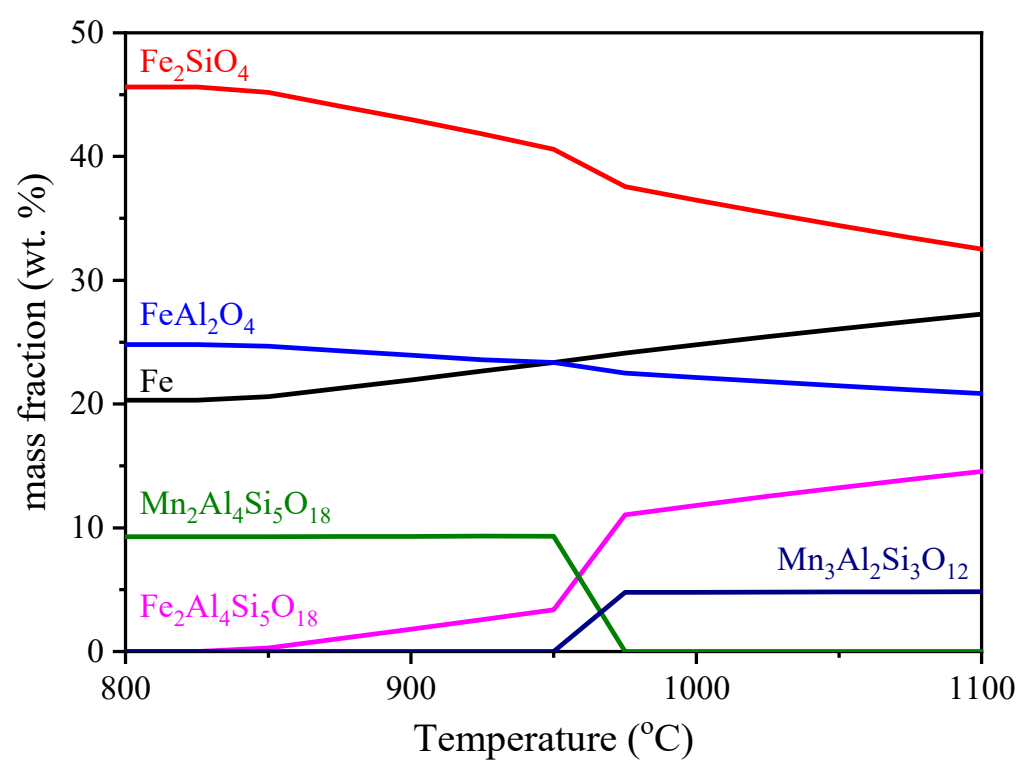

Figure 10. Thermodynamic simulation of a system consisting of $\mathrm{Fe}_{2} \mathrm{O}_{3}, \mathrm{CO}, \mathrm{SiO}_{2}, \mathrm{Al}_{2} \mathrm{O}_{3}$ and $\mathrm{MnO}$ carried out between $800^{\circ} \mathrm{C}$ and $1100^{\circ} \mathrm{C}$ in $\mathrm{CO}$ atmosphere at ambient pressure.

Combining the experimental results and simulation results, the mechanism of reducing HA ore shown in Figure 11 can be described as follows: (a), the main iron oxide hematite is deoxidized by $\mathrm{CO}$ and the intermediate product $\mathrm{FeO}$ forms; (b), $\mathrm{FeO}$ is reduced to $\mathrm{Fe}$ in $\mathrm{CO}$ atmosphere; (c), the reduction rate of $(b)$ is slow dynamically [21], and the intermediate product $\mathrm{FeO}$ reacts with the gangue minerals $\mathrm{SiO}_{2}$ and $\mathrm{Al}_{2} \mathrm{O}_{3}$ to produce $\mathrm{Fe}_{2} \mathrm{SiO}_{4}$ and $\mathrm{FeAl}_{2} \mathrm{O}_{4}$. The main products consist of $\mathrm{Fe}_{2} \mathrm{Fe}_{2} \mathrm{SiO}_{4}$ and $\mathrm{FeAl}_{2} \mathrm{O}_{4}$.

As shown in Figure 12, by synergistic reducing with $\mathrm{HM}$ ore, hercynite and fayalite are replaced by galaxite and tephroite, respectively. No fayalite but fayalite manganoan $\left((\mathrm{Fe}, \mathrm{Mn})_{2} \mathrm{SiO}_{4}\right)$ is detected when the HM ore ratio reaches $40 \%$. Meanwhile, the intensity of hercynite peak gets lower. Thermodynamically, galaxite and tephroite can be generated more easily than hercynite and fayalite, as represented in Figure 13. Thus, $\mathrm{FeO}$ can be dissociated from hercynite and fayalite by adding with $\mathrm{MnO}$, where the activity of $\mathrm{FeO}$ is improved and the reducibility of HA ore is enhanced. 


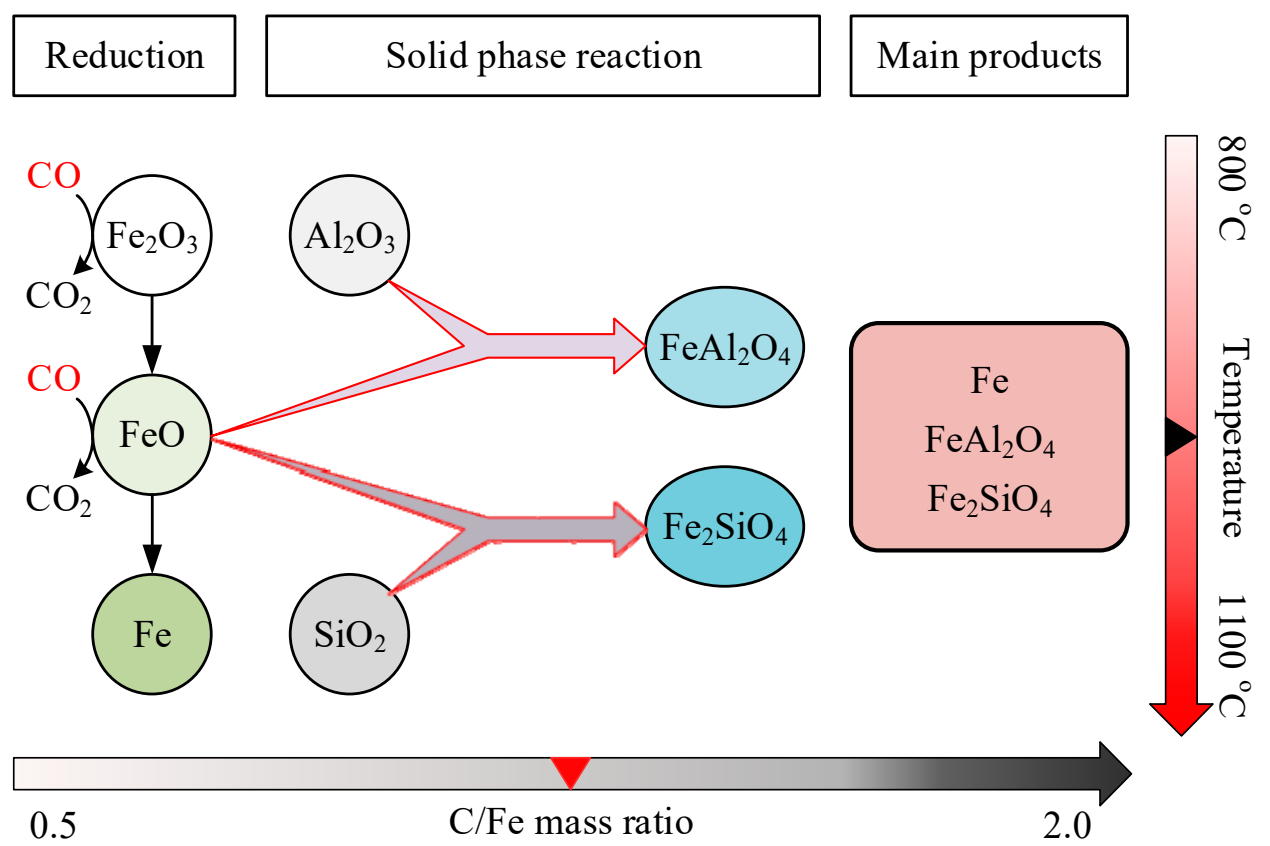

Figure 11. The mechanism of reducing high-aluminum iron ore (HA ore) by CO.

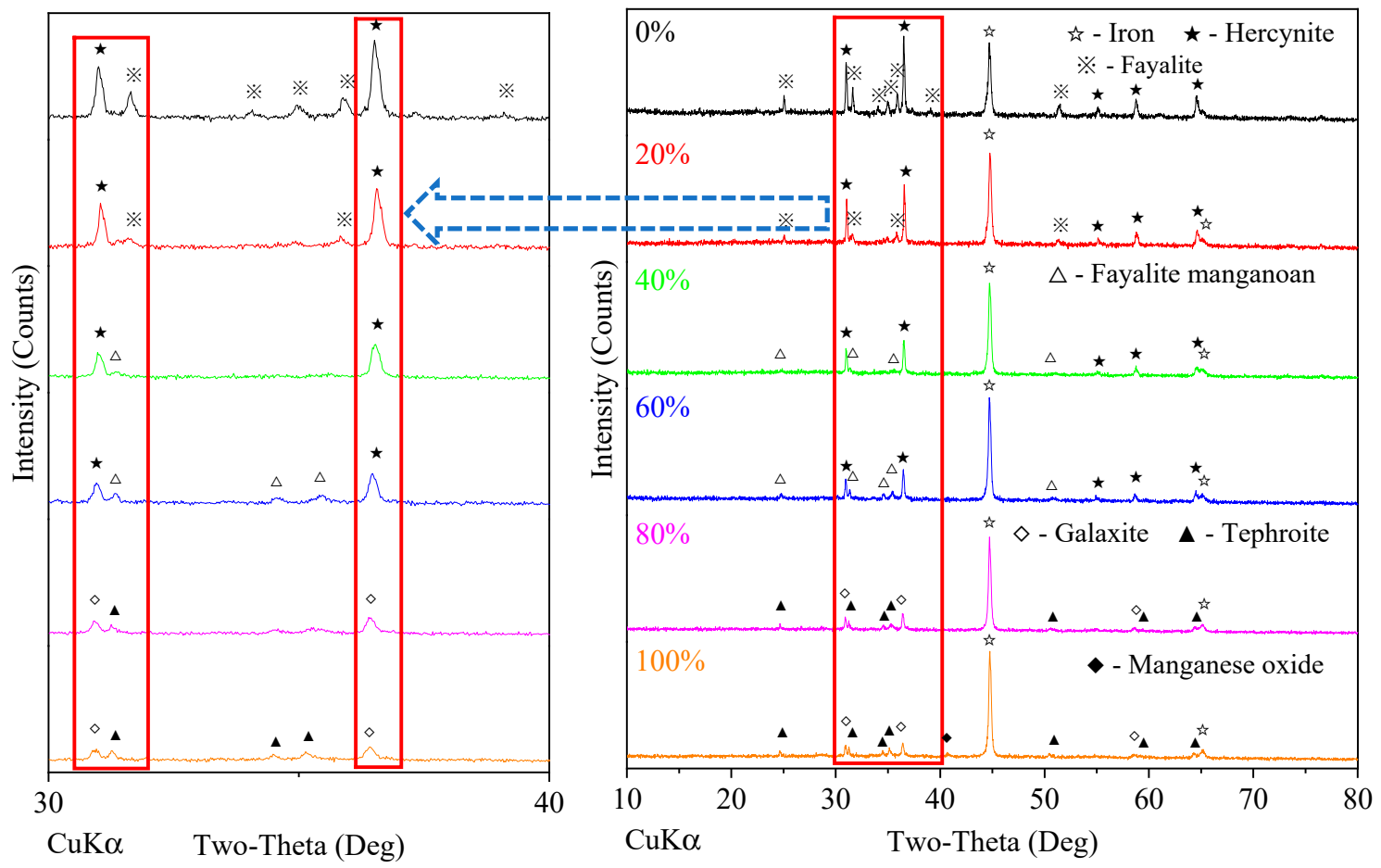

Figure 12. XRD patterns of reduced pellets with different ratio of high-maganese iron ore (HM ore) (reducing at $1050{ }^{\circ} \mathrm{C}$ for $90 \mathrm{~min}$ with $\mathrm{C} / \mathrm{Fe}$ mass ratio of 1.5). 


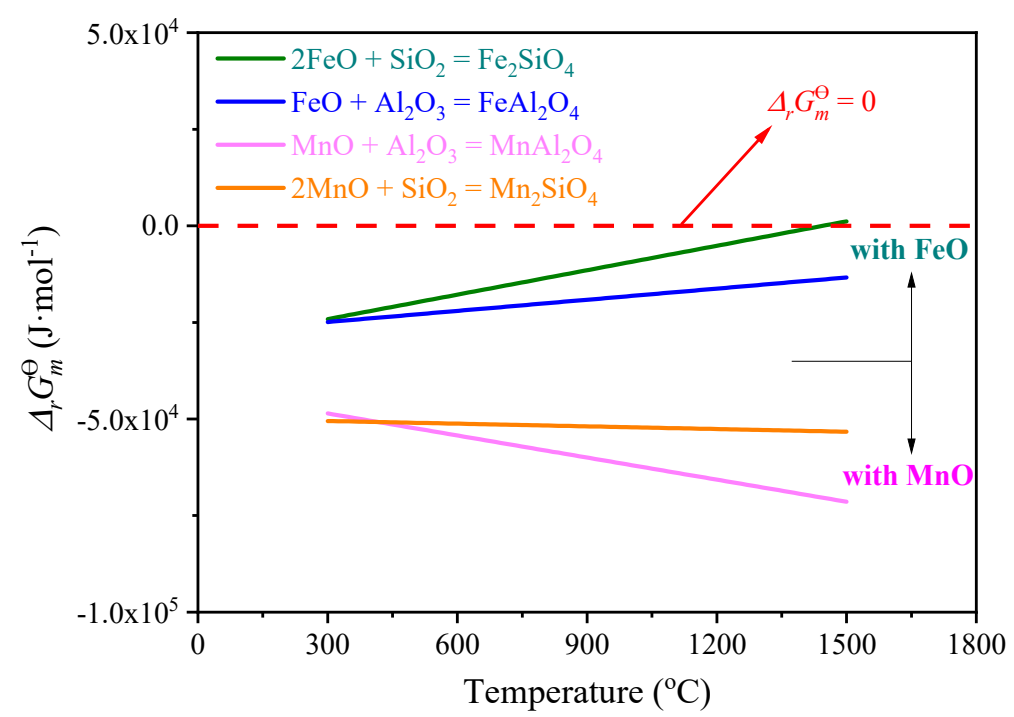

Figure 13. Comparison of standard Gibbs free energy change of reactions between $\mathrm{Al}_{2} \mathrm{O}_{3}$ and $\mathrm{SiO}_{2}$ with $\mathrm{MnO}$ and $\mathrm{FeO}$.

Another simulation based on the compositions of different $\mathrm{HM}$ ore ratio was processed by FactSage7.1, and the results are plotted in Figure 14. Less $\mathrm{Fe}_{2} \mathrm{SiO}_{4}$ and $\mathrm{FeAl}_{2} \mathrm{O}_{4}$ are produced by increasing the $\mathrm{HM}$ ore ratio, while by contrast, more Fe and Mn-Al-Si compounds are generated.

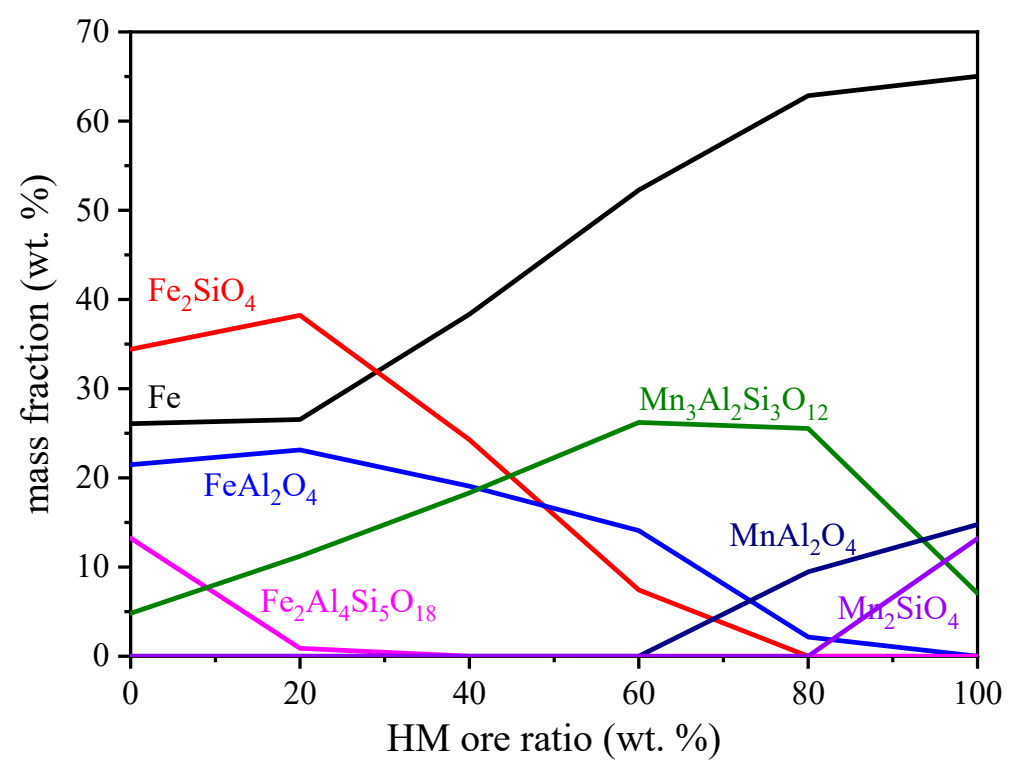

Figure 14. Thermodynamic simulation of a system consisting of $\mathrm{Fe}_{2} \mathrm{O}_{3}, \mathrm{CO}, \mathrm{SiO}_{2}, \mathrm{Al}_{2} \mathrm{O}_{3}$ and $\mathrm{MnO}$ (with different high-manganese iron ore (HM ore) ratio) carried out at $1050{ }^{\circ} \mathrm{C}$ in $\mathrm{CO}$ atmosphere at ambient pressure.

Accordingly, the mechanism of synergistic reducing of HA ore and HM ore shown in Figure 15 can be described as follows: (a) The main iron oxide hematite is deoxidized by $\mathrm{CO}$ and the intermediate product $\mathrm{FeO}$ forms; (b) $\mathrm{FeO}$ reacts with the gangue minerals $\mathrm{SiO}_{2}$ and $\mathrm{Al}_{2} \mathrm{O}_{3}$ to produce $\mathrm{Fe}_{2} \mathrm{SiO}_{4}$ and $\mathrm{FeAl}_{2} \mathrm{O}_{4}$; (c) $\mathrm{MnO}$ from $\mathrm{HM}$ ore combines with $\mathrm{Fe}_{2} \mathrm{SiO}_{4}$ and $\mathrm{FeAl}_{2} \mathrm{O}_{4}$ to form $\mathrm{Mn}_{2} \mathrm{SiO}_{4}, \mathrm{MnAl}_{2} \mathrm{O}_{4}$ and $\mathrm{FeO}$; (d) $\mathrm{FeO}$ is reduced to $\mathrm{Fe}$ in $\mathrm{CO}$ atmosphere. The main products consist of $\mathrm{Fe}, \mathrm{Mn}_{2} \mathrm{SiO}_{4}$ and $\mathrm{MnAl}_{2} \mathrm{O}_{4}$. 


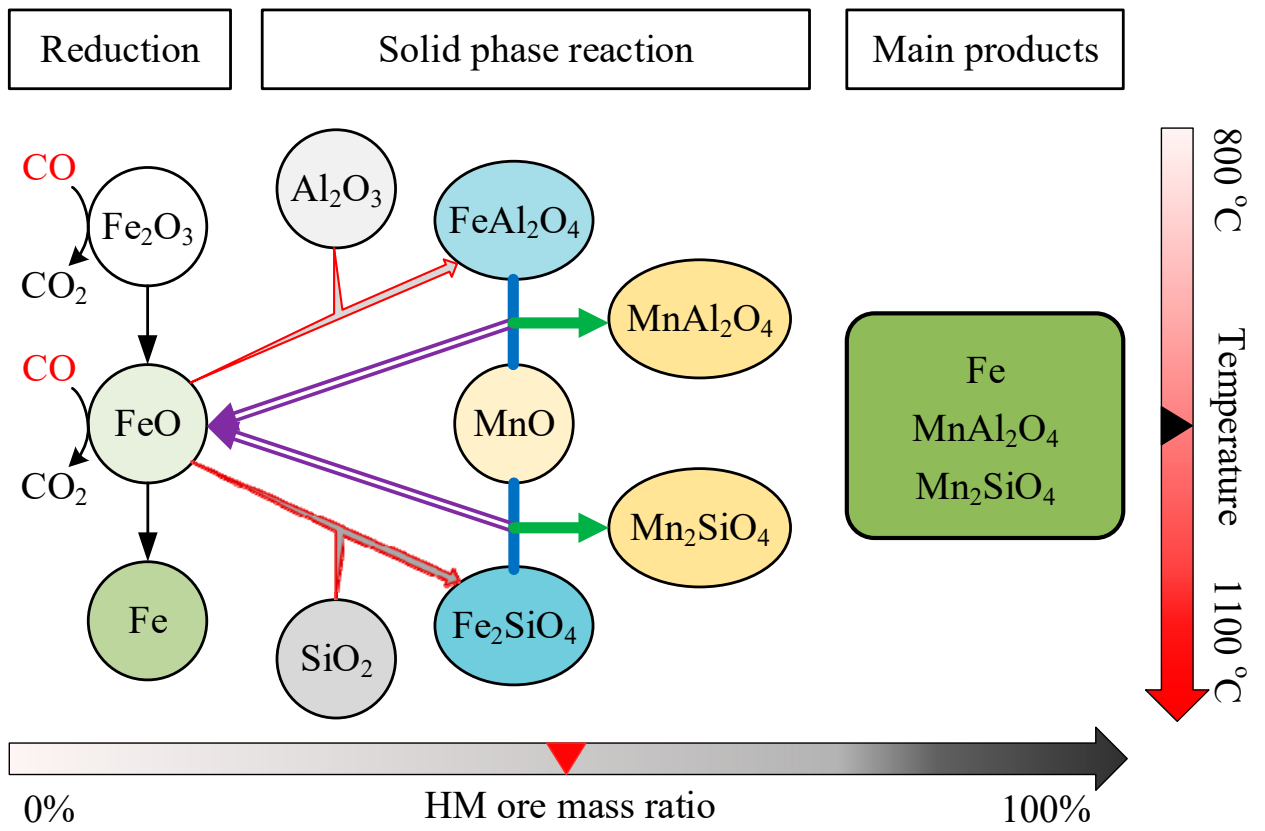

Figure 15. The mechanism of synergistic reducing of high-aluminum iron ore (HA ore) and high-manganese iron ore (HM ore) by CO.

\section{Conclusions}

In this study, a mechanism for enhancing the reduction of high-aluminum iron ore by synergistic reducing with high-manganese iron ore was investigated. The conclusions can be summarized as follows:

(1) Because of the generation of hercynite and fayalite, only $66.49 \%$ of metallization degree is obtained by reducing the high-aluminum iron ore containing $41.92 \% \mathrm{Fe}_{\text {total }}$, and $13.74 \% \mathrm{Al}_{2} \mathrm{O}_{3}$ under $1050{ }^{\circ} \mathrm{C}$ for $120 \mathrm{~min}$ with $\mathrm{C} / \mathrm{Fe}$ mass ratio of 1.5. By synergistic reducing with a high-manganese iron ore assaying $9.24 \% \mathrm{Mn}_{\text {total }}$, a higher metallization degree is achieved. Over $90 \%$ of the metallization degree is obtained by adding with $60 \%$ of the high-manganese iron ore.

(2) The mechanism of reducing HA ore can be described as follows: (a) the main iron oxide hematite is deoxidized by $\mathrm{CO}$ and the intermediate product $\mathrm{FeO}$ forms; (b) $\mathrm{FeO}$ reacts with the gangue minerals $\mathrm{SiO}_{2}$ and $\mathrm{Al}_{2} \mathrm{O}_{3}$ to produce $\mathrm{Fe}_{2} \mathrm{SiO}_{4}$ and $\mathrm{FeAl}_{2} \mathrm{O}_{4} ;$ (c) $\mathrm{FeO}$ is reduced to $\mathrm{Fe}$ in $\mathrm{CO}$ atmosphere. The main products consist of $\mathrm{Fe}, \mathrm{Fe}_{2} \mathrm{SiO}_{4}$ and $\mathrm{FeAl}_{2} \mathrm{O}_{4}$.

(3) The mechanism of synergistic reducing of HA ore and HM ore can be described as: (a) the main iron oxide hematite is deoxidized by $\mathrm{CO}$ and the intermediate product $\mathrm{FeO}$ forms; (b) $\mathrm{FeO}$ reacts with the gangue minerals $\mathrm{SiO}_{2}$ and $\mathrm{Al}_{2} \mathrm{O}_{3}$ to produce $\mathrm{Fe}_{2} \mathrm{SiO}_{4}$ and $\mathrm{FeAl}_{2} \mathrm{O}_{4}$; (c) $\mathrm{MnO}$ from $\mathrm{HM}$ ore combines with $\mathrm{Fe}_{2} \mathrm{SiO}_{4}$ and $\mathrm{FeAl}_{2} \mathrm{O}_{4}$ to form $\mathrm{Mn}_{2} \mathrm{SiO}_{4}, \mathrm{MnAl}_{2} \mathrm{O}_{4}$ and $\mathrm{FeO}$; (d) $\mathrm{FeO}$ is reduced to $\mathrm{Fe}$ in $\mathrm{CO}$ atmosphere. The main products consist of $\mathrm{Fe}, \mathrm{Mn}_{2} \mathrm{SiO}_{4}$ and $\mathrm{MnAl}_{2} \mathrm{O}_{4}$.

Author Contributions: X.Z. and DZ. conceived of and designed the experiments. X.Z. and Y.L. performed the experiments and analyzed the data. D.Z. contributed materials. X.Z. and Y.L. wrote the paper. D.Z. and T.C. modified the paper.

Funding: This research was funded by Hubei Key Laboratory for Efficient Utilization and Agglomeration of Metallurgic Mineral Resources (No. 2017zy002, No. 2017zy012), Wuhan University of Science and Technology (No. 2017xz013) and National Natural Science Foundation of China (No. 51574281).

Acknowledgments: This work was financially supported by Hubei Key Laboratory for Efficient Utilization and Agglomeration of Metallurgic Mineral Resources, Wuhan University of Science and Technology and National Natural Science Foundation of China.

Conflicts of Interest: The authors declare no conflict of interest. 


\section{References}

1. World Steel Association Economics Committee. Steel Statistical Yearbook 2018; World Steel Association: Brussels, Belgium, 2018; p. 104.

2. Zhang, K.; Kleit, A.N. Mining rate optimization considering the stockpiling: A theoretical economics and real option model. Resour. Policy 2016, 47, 87-94. [CrossRef]

3. Samouhos, M.; Taxiarchou, M.; Pilatos, G.; Tsakiridis, P.E.; Devlin, E.; Pissas, M. Controlled reduction of red mud by $\mathrm{H}_{2}$ followed by magnetic separation. Miner. Eng. 2017, 105, 36-43. [CrossRef]

4. Chun, T.; Long, H.; Li, J. Alumina-Iron Separation of High Alumina Iron Ore by Carbothermic Reduction and Magnetic Separation. Sep. Sci. Technol. 2015, 50, 760-766. [CrossRef]

5. Lu, L.; Holmes, R.J.; Manuel, J.R. Effects of alumina on sintering performance of hematite iron ores. ISIJ Int. 2007, 47, 349-358. [CrossRef]

6. Raghukumar, C.; Tripathy, S.K.; Mohanan, S. Beneficiation of Indian High Alumina Iron Ore Fines-A Case Study. Int. J. Min. Eng. Miner. Proc. 2012, 1, 94-100. [CrossRef]

7. Liu, Z.; Li, H. Metallurgical process for valuable elements recovery from red mud-A review. Hydrometallurgy 2015, 155, 29-43. [CrossRef]

8. Thella, J.S.; Mukherjee, A.K.; Srikakulapu, N.G. Processing of high alumina iron ore slimes using classification and flotation. Powder Technol. 2012, 217, 418-426. [CrossRef]

9. Chun, T.; Li, D.; Di, Z.; Long, H.; Tang, L.; Li, F.; Li, Y. Recovery of iron from red mud by high-temperature reduction of carbon-bearing briquettes. J. S. Afr. Inst. Min. Metall. 2017, 117, 361-364. [CrossRef]

10. Li, G.; Jiang, T.; Liu, M.; Zhou, T.; Fan, X.; Qiu, G. Beneficiation of High-Aluminium-Content Hematite Ore by Soda Ash Roasting. Min. Proc. Extr. Met. Rev. 2010, 31, 150-164. [CrossRef]

11. Chun, T.J.; Zhu, D.Q.; Pan, J.; He, Z. Preparation of metallic iron powder from red mud by sodium salt roasting and magnetic separation. Can. Metall. Quart. 2014, 53, 183-189. [CrossRef]

12. Sutar, H.; Mishra, S.C.; Sahoo, S.K.; Chakraverty, A.P.; Maharana, H.S. Progress of red mud utilization: An overview. Am. Chem. Sci. J. 2014, 4, 255-279. [CrossRef]

13. Wang, H.; She, X.; Zhao, Q.; Xue, Q.; Wang, J. Production of iron nuggets using iron-rich red mud by direct reduction. Chin. J. Proc. Eng. 2012, 12, 816-821.

14. Borra, C.R.; Blanpain, B.; Pontikes, Y.; Binnemans, K.; Van Gerven, T. Smelting of Bauxite Residue (Red Mud) in View of Iron and Selective Rare Earths Recovery. J. Sustain. Met. 2016, 2, 28-37. [CrossRef]

15. He, P.; Ju, D.; Shen, P.; Jin, H. Experimental research on comprehensive utilization of red mud based on direct reduction and melting by RHF iron bead technology. Energ. Metall. Ind. 2017, 36, 57-60.

16. Stjernberg, J.; Olivas-Ogaz, M.A.; Antti, M.L.; Ion, J.C.; Lindblom, B. Laboratory scale study of the degradation of mullite/corundum refractories by reaction with alkali-doped deposit materials. Ceram. Int. 2013, 39, 791-800. [CrossRef]

17. Gan, L.; Xu, J.; Zhang, Z.; Liang, Y.; Wei, M.; Wen, C. Red Mud Pellets and Its Preparation Method. CN103602805A, 26 February 2014.

18. Shankar, A. Studies on High Alumina Blast Furnace Slags. Ph.D. Thesis, Royal Institute of Technolog, Stockholm, Sweden, 15 June 2007.

19. Zhou, X.; Zhu, D.; Pan, J.; Luo, Y.; Liu, X. Upgrading of High-Aluminum Hematite-Limonite Ore by High Temperature Reduction-Wet Magnetic Separation Process. Metals 2016, 6, 57. [CrossRef]

20. Donskoi, E.; Olivares, R.I.; McElwain, D.L.S.; Wibberley, L.J. Experimental study of coal based direct reduction in iron ore/coal composite pellets in a one layer bed under nonisothermal, asymmetric heating. Ironmak. Steelmak. 2006, 33, 24-28. [CrossRef]

21. Zhu, D.; Luo, Y.; Pan, J.; Zhou, X. Reaction Mechanism of Siderite Lump in Coal-Based Direct Reduction. High Temp. Mater. Procees. 2016, 35, 185-194. [CrossRef]

(C) 2018 by the authors. Licensee MDPI, Basel, Switzerland. This article is an open access article distributed under the terms and conditions of the Creative Commons Attribution (CC BY) license (http:/ / creativecommons.org/licenses/by/4.0/). 